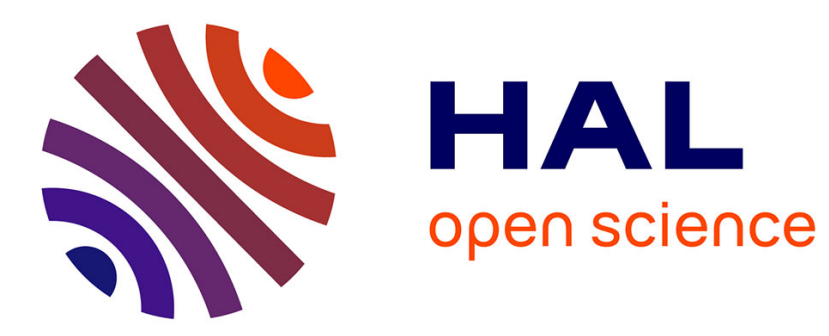

\title{
Water Content of CO 2 rich Mixtures: Measurements and Modeling using the Cubic-Plus-Association Equation of State
}

Antonin Chapoy, Rod Burgass, Alexandre Terrigeol, Christophe Coquelet

\section{- To cite this version:}

Antonin Chapoy, Rod Burgass, Alexandre Terrigeol, Christophe Coquelet. Water Content of CO 2 rich Mixtures: Measurements and Modeling using the Cubic-Plus-Association Equation of State. Journal of Natural Gas Engineering , 2016, 1 (13), pp.85-97. 10.7569/JNGE.2015.692505 • hal-01305689

\section{HAL Id: hal-01305689}

https://hal-mines-paristech.archives-ouvertes.fr/hal-01305689

Submitted on 21 Apr 2016

HAL is a multi-disciplinary open access archive for the deposit and dissemination of scientific research documents, whether they are published or not. The documents may come from teaching and research institutions in France or abroad, or from public or private research centers.
L'archive ouverte pluridisciplinaire HAL, est destinée au dépôt et à la diffusion de documents scientifiques de niveau recherche, publiés ou non, émanant des établissements d'enseignement et de recherche français ou étrangers, des laboratoires publics ou privés. 


\title{
Water Content of $\mathrm{CO}_{2}$ rich Mixtures: Measurements and Modeling using the Cubic-Plus-Association Equation of State
}

\author{
Antonin CHAPOY ${ }^{1,3, *}$, Rod BURGASS ${ }^{1}$, Alexandre TERRIGEOL ${ }^{2}$ and Christophe \\ COQUELET ${ }^{3, *}$
}

\author{
${ }^{1}$ Heriot Watt University, Hydrates, Flow Assurance \& Phase Equilibria, Institute of \\ Petroleum Engineering, Edinburgh EH14 4AS, United Kingdom \\ ${ }^{2}$ CECA SA, Molecular Sieve business unit, 89, Boulevard National, 92250 La Garenne \\ Colombes, France \\ ${ }^{3}$ MINES ParisTech, PSL research university, CTP-Centre of Thermodynamic of Processes \\ 35, Rue Saint Honoré, 77305 Fontainebleau, France
}

\begin{abstract}
Natural gas is well known as the cleanest fossil fuel. However, it is estimated that more than $40 \%$ of the remaining conventional natural gas reserves are deemed to be acidic, i.e., containing significant quantities of $\mathrm{CO}_{2}$ and $\mathrm{H}_{2} \mathrm{~S}$. As the global consumption of natural gas is expected to steadily grow, the demand will be met by sources such as sour/acid gas fields. In some specific applications that require cryogenic processes (LNG, NGL recovery), this issue is commonly addressed upstream of the gas dehydration unit, so that the gas is already sweet when arriving at the drying section. In the other cases, the effect of the acidic species on the gas water content is often not properly accounted for, even though an accurate appraisal of the water content is paramount for the sizing of dehydration units.

In this contribution, the water contents of the ternary system $\mathrm{CO}_{2}+\mathrm{CH}_{4}+\mathrm{H}_{2} \mathrm{O}$ were determined for various $\mathrm{CO}_{2}$ to $\mathrm{CH}_{4}$ ratios. New experimental data were obtained using a Tuneable Diode Laser Spectroscopy (TDLS) setup, with an accuracy of $+/-1 \%$. The SoaveRedlich-Kwong and the Peng Robinson equations of state combined with the Cubic-Plus Association were used to estimate water content on $\mathrm{CO}_{2}$ rich gas mixtures.
\end{abstract}

Key words: Carbon Dioxide; CPA; Equation of state; Methane; Water content; PengRobinson; Soave-Redlich-Kwong.

\footnotetext{
* Corresponding authors:
}

E-mail: antonin.chapoy@pet.hw.ac.uk

E-mail: christophe.coquelet@mines-paristech.fr 


\section{INTRODUCTION}

The consumption of natural gas is expected to steadily grow, and the demand will increasingly be met by sources such as sour/acid gas fields. This will have an impact on the whole gas processing chain, and especially on gas dehydration. Accurate assessment of the influence of acid gases, in particular $\mathrm{CO}_{2}$, on the gas water content, which impacts on the size of dehydration unit required, is still today incomplete, as publicly available data are scarce.

In the case of a sweet gas, the water content can be calculated by phase equilibria-based commercial softwares, or estimated using the McKetta and Wehe chart [1]. Water content assessment is much more challenging when it comes to acid gas. As both pure $\mathrm{H}_{2} \mathrm{~S}$ and $\mathrm{CO}_{2}$ contain more water at saturation than sweet natural gas, their effect on the overall water content can be very significant.

Several sets of experimental data and charts are available to address the subject. In this regard, the GPSA Engineering Handbook gives a good overview of the available methods [2]. However and as correctly pointed out by the GPSA, most of these methods apply to a reduced range of conditions, and/or give discrete information for limited sets of compositions. Generally speaking, the literature of the past 50 years is poor on the subject. As a consequence of this, the reliability of the results is very often questionable in terms of accuracy.

In practice, in most of the cases, the problem mainly concerns $\mathrm{CO}_{2}$, with contents sometimes up to $30-50 \%$, while the $\mathrm{H}_{2} \mathrm{~S}$ level is generally much lower, and therefore of a very limited impact compared to $\mathrm{CO}_{2}$. This is the reason why in this article the focus is on the influence of $\mathrm{CO}_{2}$.

The following "simplified" example illustrates the importance of having a good estimation of the water content, and its influence on a molecular sieve dehydration unit. In the following discussion, it is assumed that the gas to be treated has the characteristics listed in Table 1. 


\begin{tabular}{|lcl|}
\hline $\begin{array}{l}\text { Table 1. Gas compositions and } \\
\text { properties }\end{array}$ \\
\hline Flow-rate & 200000 & $\mathrm{Nm}^{3} / \mathrm{hr}$ \\
Pressure & 60 & $\mathrm{Bara}$ \\
Temperature & 25 & ${ }^{\circ} \mathrm{C}$ \\
Composition (mol\%): & & \\
\hline $\mathrm{C}_{1}$ & 50 & $\%$ \\
$\mathrm{CO}_{2}$ & 40 & $\%$ \\
$\mathrm{C}_{2}$ & 8 & $\%$ \\
$\mathrm{C}_{3}$ & 2 & $\%$ \\
\hline
\end{tabular}

Under these conditions, if the gas was considered as a sweet gas, and the water content estimated by the McKetta-Wehe chart, the design of the unit would be based on $690 \mathbf{p p m V}$ water content (Case 1). Taking into account the influence of $\mathrm{CO}_{2}$, the real water content of the gas is in fact 770 ppmV, about12\% higher (Case 2). The dehydration unit has to meet the following outlet specifications (Table 2):

\begin{tabular}{|ll|}
\hline Table 2. Dehydration unit specifications \\
\hline Water content: & $<1 \mathrm{ppmV}$ \\
Pressure drop: & $<0.35 \mathrm{bar}$ (end of lifetime) \\
Lifetime: & $>4$ years \\
\hline
\end{tabular}

From this very simplified Process Specification, The impact of the two water contents on the unit design will be assessed.

\begin{tabular}{|lcc|}
\hline \multicolumn{3}{|l|}{ Table 3. Dehydration unit design } \\
\hline & Case 1 & Case 2 \\
& $(690 \mathrm{ppmV})$ & $(770 \mathrm{ppmV})$ \\
\# of vessels in adsorption & 1 & 1 \\
Vessel diameter (mm) & 2900 & 2950 \\
Mole sieve quantity (kg) & 11900 & 13050 \\
Adsorption time (hrs) & 12 & 12 \\
\hline
\end{tabular}

With an inlet water content of $690 \mathrm{ppmV}$, a typical design meeting the specification given in Table 2 would involve 11.9 metric tons of molecular sieve and 12 hours adsorption time (Table 3). If the design of Case 1 was applied with the water content of Case 2 was, the additional water content would lead to either one of the following scenario: 
- If 12 hours adsorption time and original flow-rate were maintained, the lifetime of the unit would decrease from 4 years to only 1.5 to 2 years maximum.

- To maintain a 4 years lifetime and 12 hours adsorption time, the flow-rate would have to be decreased from $200,000 \mathrm{Nm}^{3} / \mathrm{hr}$ down to $\sim 180,000 \mathrm{Nm}^{3} / \mathrm{hr}$.

By taking into account the real water content of the gas, the resulting design to allow for 4 years lifetime at the stated flow-rate would be significantly different. It would involve a slightly larger vessel diameter, and $\sim 10 \%$ more mole sieve (Table 3 ).

The above example stresses the fact that an incorrect water content assessment can significantly influence the operation of an existing unit. As mentioned in Terrigeol et al. [4] it is preferable to use a correlation in order to have a quick indication of the water content of gas mixtures containing $\mathrm{CO}_{2}$ and $\mathrm{CH}_{4}$.

The aim of this work is to correctly assess the water content in $\mathrm{CO}_{2}$ rich gases, for this purpose a review of the experimental data will be made. In order to evaluate the thermodynamic models, new experimental data for water content of binary mixtures of methane and carbon dioxide were generated.

\section{LITERATURE REVIEW}

Phase equilibrium data are widely available for the $\mathrm{CO}_{2}+\mathrm{CH}_{4}, \mathrm{CO}_{2}+\mathrm{H}_{2} \mathrm{O}$ and $\mathrm{CH}_{4}+\mathrm{H}_{2} \mathrm{O}$ binary systems, however data for the ternary systems to validate the thermodynamic model are rather limited, in particular water content data are scarce. Sharma [5] and Song and Kobyashi [6] have measured the water content for the ternary systems. Song and Kobyashi [6] have measured the water content for a gas mixture composed with $94.69 \%$ of $\mathrm{CO}_{2}$ and $5.31 \%$ of $\mathrm{CH}_{4}$. Dhima et al. [7] have measured the solubility of methane and carbon dioxide in water at $344 \mathrm{~K}$ and Quin et al. [8] have measured both liquid and vapour compositions at 324 and $375 \mathrm{~K}$. 


\section{EXPERIMENTAL}

\subsection{Materials}

The $\mathrm{CO}_{2}$ was $99.99 \%$ pure and the $\mathrm{CH}_{4}$ was $99.995 \%$ pure, both were supplied by BOC. The $\mathrm{CO}_{2} / \mathrm{CH}_{4}$ binary mixtures were made using gravimetric means. The accuracy of the mixture compositions is \pm 0.1 mole\%. Deionized water was used in all tests.

\subsection{Experimental setup}

In order to validate the thermodynamic model, new experimental data were measured. The core of the equipment for water content measurement and the procedures have been originally described by Chapoy et al. [9] and Burgass et al. (2014) [10]. The setup is comprised of twin equilibrium cells and a device for measuring the water content of equilibrated fluids passed from the cell. The twin equilibrium cell consists of 2 piston-type variable volume (maximum effective volume of $300 \mathrm{ml}$ ), titanium cylindrical pressure vessel held within a single cooling jacket (Figure 1). Cell volume, hence pressure, can be adjusted by injecting/withdrawal of hydraulic liquid behind the moving piston. The rig has a working temperature range of 203.15 to $453.15 \mathrm{~K}$, with a maximum operating pressure of $70 \mathrm{MPa}$. The moisture/water content measurement set-up consists of a heated line, a Tuneable Diode Laser Adsorption Spectroscopy (TDLAS) from Yokogawa and a flow meter. The unit has two measurement ranges 0-100 ppmV and 0-3000 ppmV, both having a stated standard uncertainty of $\pm 1 \%$ of full scale $\left(\mathrm{u}\left(y_{w}\right)=1\right.$ or $\left.30 \mathrm{ppmV}\right)$. Taking into account the error / repeatability between samples, the expanded combined uncertainty for water content is calculated to be $\mathrm{U}_{\mathrm{c}}\left(y_{w}\right)=0.0006$ mole $\%$. 


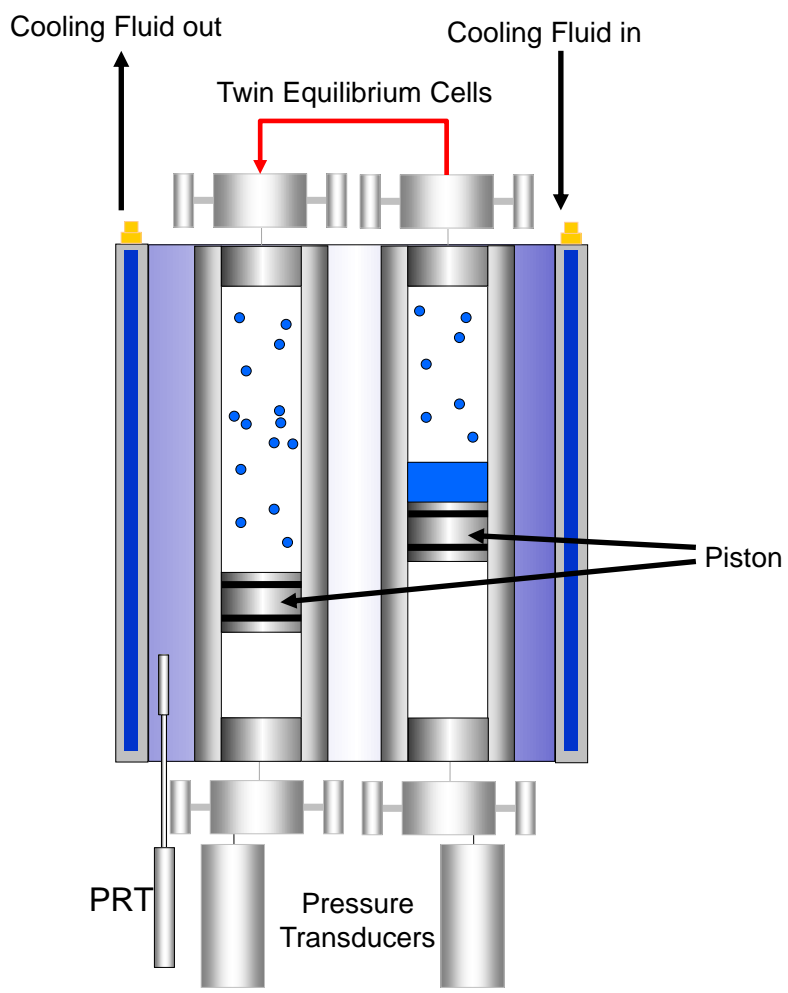

Figure 1: Schematic diagram showing equilibrium cell and water content measurement setup.

System temperature is controlled by circulating coolant from a cryostat within a jacket surrounding the cell. The equilibrium cell and pipework were thoroughly insulated to ensure constant temperature. The temperature was measured and monitored by means of a PRT (Platinum Resistance Thermometers) located within the cooling jacket of the cell. Two Quartzdyne QS 30K-B pressures transducers connected to the bottom of the cells on the hydraulic are used to measure the pressure of the system. Both pressures transducers were previously calibrated against a deadweight tester and the temperature probe by comparison against a certified high precision probe. This calibration procedure ensures expanded uncertainties $(k=2)$ better than $u(P)=0.04 \mathrm{MPa}$ and $u(T)=0.1 \mathrm{~K}$.

At the start of a test around $3 \mathrm{ml}$ of deionized water was placed in a cup shaped depression in the bottom of the piston. The cell was then closed and evacuated before injecting the test gas. The cell temperature and pressure were then adjusted to achieve the desired test conditions. The cell was then allowed to equilibrate for at least 20 hours. This has been confirmed as being sufficient time for equilibrium to be achieved by conducting water content measurements over a number of days in previous testing. 


\subsection{Procedures}

Once equilibrium had been achieved the valve at the top of the cell was opened in order to fill the section of heated line up to the valve prior to the hygrometer at the same time test gas was introduced into the base of the cell in order to maintain the pressure constant. Following this, the valve prior (inlet) to the hygrometer was opened sufficiently to achieve a flow rate of between 0.5 and 1 liter per minute through the hygrometer. The water content reading from the TDLS analyzer was then monitored until it was stable for at least 10 minutes. This was then taken as the moisture content of the equilibrated fluid in the cell (i.e., flowing out of the cell). During sampling the heated line was maintained at a temperature of $433.15 \mathrm{~K}$.

\section{THERMODYNAMIC MODELLING - THE PR-CPA}

In this work, the models developed by Chapoy et al. [9] and Hajiw et al. used [11-12] have been used. In summary, the thermodynamic models are based on the uniformity of fugacity of each component throughout all the phases. The fugacities are calculated using the CPA-EoS coupled with the original Soave-Redlich and Kwong and the Peng-Robinson EoS [13].

For non-associating compounds, the CPA-EoS reduced to the SRK-EoS or PR EoS. All parameters for the CPA-SRK can be found in Chapoy et al. [9]. The PR-CPA parameters for water reported by Hajiw et al. used [11-12] were used in this work. Predictions for the $\mathrm{CH}_{4}+$ $\mathrm{H}_{2} \mathrm{O}$ and $\mathrm{CO}_{2}+\mathrm{H}_{2} \mathrm{O}$ are shown in Figures 2 and 3.
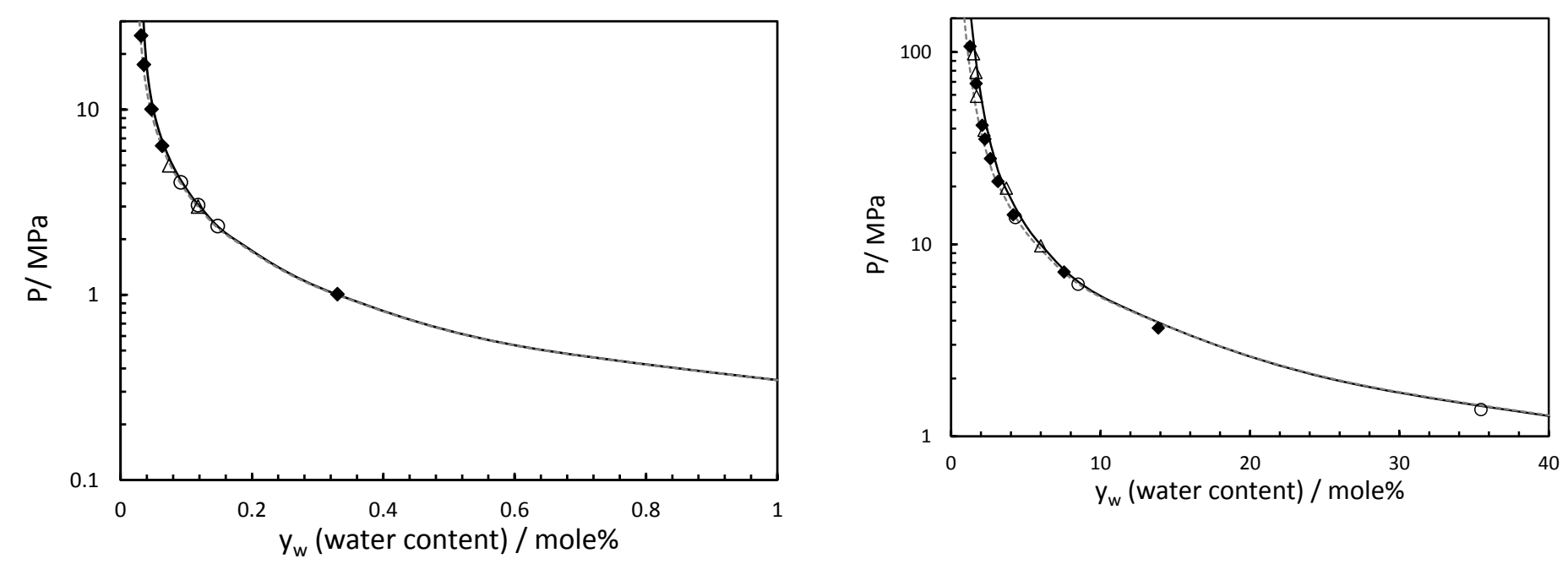

Figure 2. Py, Phase equilibria in the methane + water system at $298.15 \mathrm{~K}$ (left) and $423.15 \mathrm{~K}$ (right). Black Lines: Model predictions using the CPA-PR. Grey dashed lines: Model predictions using the CPA-SRK. At 
298.15 K: ( $\Delta)$ experimental data from [14], (O) experimental data from [15], experimental data from [16]. At about $423 \mathrm{~K}:(\diamond)$ experimental data from [17], ( $\triangle)$ experimental data from [18], (O) experimental data from [19].
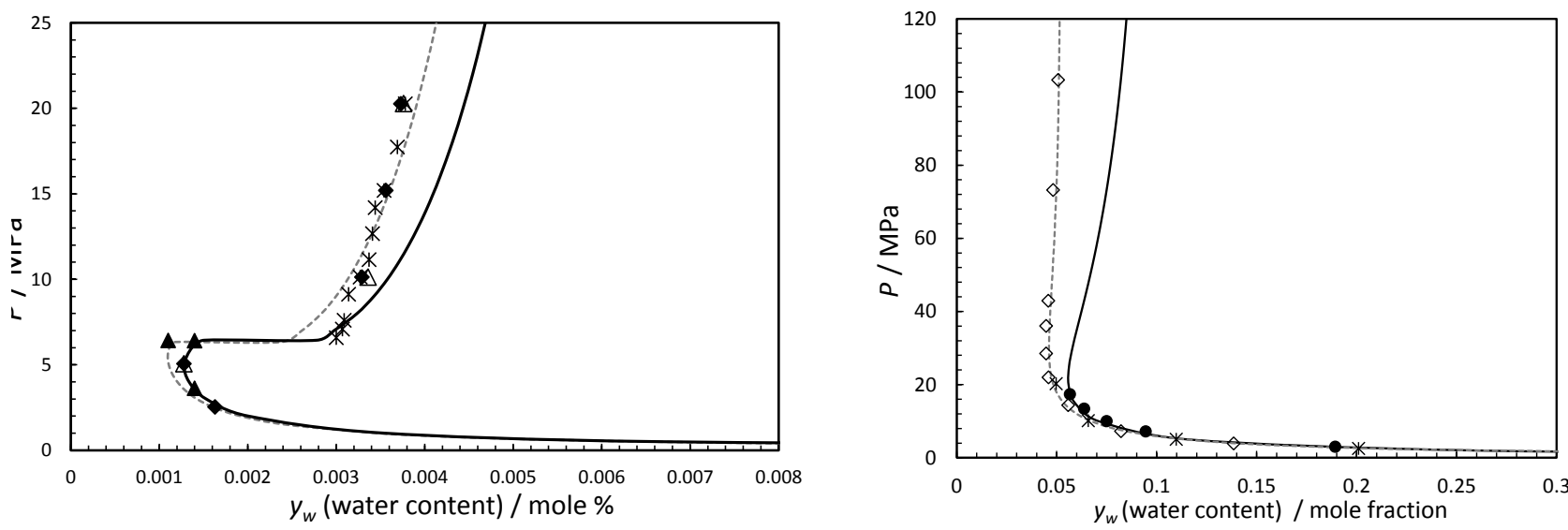

Figure 3. Py, Phase equilibria in the carbon dioxide + water system at $298.15 \mathrm{~K}$ (left) and 423.15 K (right). Black Lines: Model predictions using the CPA-PR. Grey dashed lines: Model predictions using the CPA-SRK. Left figure: ( $\bullet$ experimental data from [20]; $(\Delta)$ [21]; ( $\Delta$ ) experimental data from [22]; ( $*$ ) experimental data from [23]; ( $\diamond)$ experimental data from [24]. Right figure :( $*)$ experimental data from [21]; ( $)$ experimental data from [19]; (O) experimental data from [25].

The only water content data available for the ternary system are the data presented by Song and Kobayashi [5]. They have measured the water content in 94.69 mole\% $\mathrm{CO}_{2}+5.31$ mole $\% \mathrm{CH}_{4}$ system. Their data at $323.15 \mathrm{~K}$ are shown in Figure 4 along with the predictions of the model and literature data for pure $\mathrm{CO}_{2}$ and $\mathrm{CH}_{4}$ at the same temperature. 

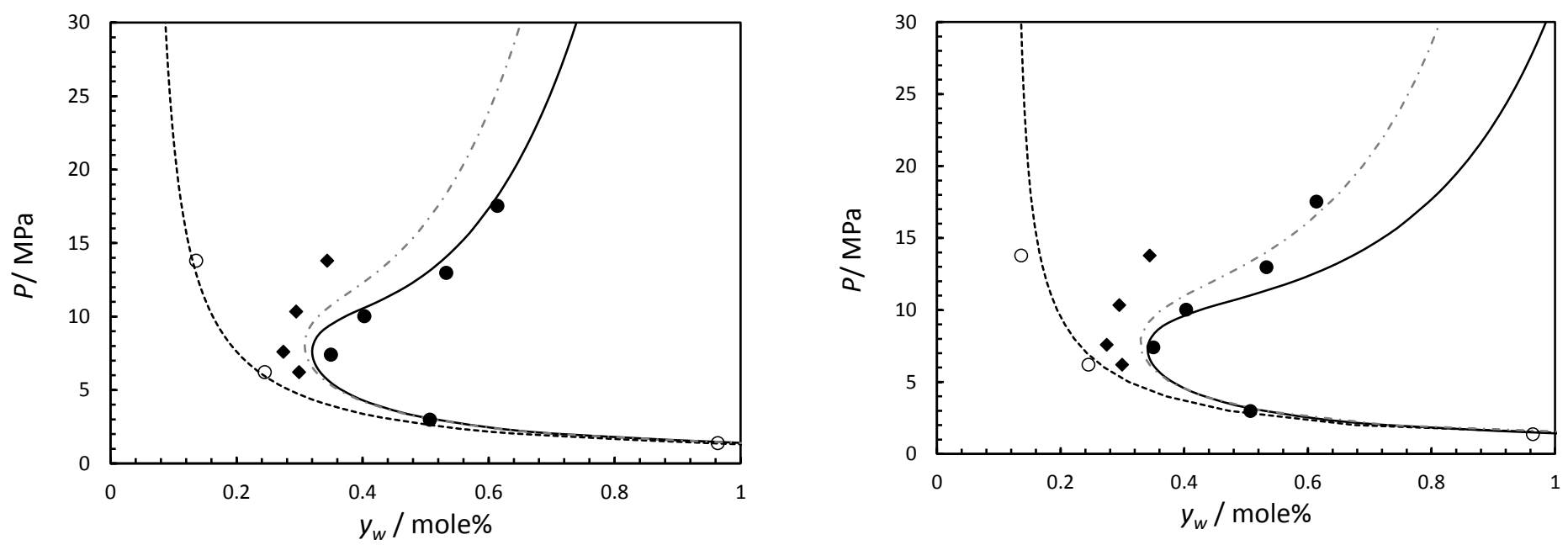

Figure 4. Py, Water content in the $\mathrm{CH}_{4}, 94.69$ mole\% $\mathrm{CO}_{2}+5.31$ mole \% $\mathrm{CH}_{4}$ and $\mathrm{CO}_{2}$ systems at $323.15 \mathrm{~K}$. Left Figure: Predictions using the CPA-SRK. Right Figure: Predictions using the CPA-PR. Black Lines: Model predictions for $\mathrm{CO}_{2}$. Dotted black lines: Model predictions $\mathrm{CH}_{4 .}$ Grey broken lines: Model predictions for the 94.69 mole\% $\mathrm{CO}_{2}+5.31$ mole \% $\mathrm{CH}_{4}$ ( $\diamond$ experimental data [6]; (O):experimental data [21];(O): experimental data [25].

As can be seen in the figure, the models can accurately predict the experimental water content in the pure fluids with the CPA-SRK superior to the CPA-PR in this case; however the water content predicted by the model for the ternary is higher than the one experimentally measured by Song and Kobayashi [6]. It is planned to measure water content for a similar system as the data for the binary $\mathrm{CO}_{2}+$ water of these authors have been questioned by other researchers [9$10,26]$.

\section{RESULTS AND DISCUSSIONS}

The new experimental water content measurements for three gas mixtures of $\mathrm{CH}_{4}$ and $\mathrm{CO}_{2}$ at the different test conditions are shown in Table 4. Low deviations of the new experimental data set confirm their consistency. Overall the predictions with the CPA-SRK are better than those made with the CPA-PR (Figure 5). CPA-PR seems to over predict the water content at these experiment conditions. Looking at the predictions for the binary $\mathrm{CO}_{2}$ and water systems (Figure 3), it can be seen that higher deviations are generally observed for the CPA-PR, especially in denser phase. 


\begin{tabular}{|c|c|c|c|c|c|c|}
\hline \multirow{2}{*}{$\begin{array}{c}\text { Mole\% } \\
\mathrm{CO}_{2}\end{array}$} & \multirow{2}{*}{$\begin{array}{c}\text { Mole\% } \\
\mathrm{CH}_{4}\end{array}$} & \multirow[t]{2}{*}{$T / \mathrm{K}$} & \multirow[t]{2}{*}{$P / \mathrm{MPa}$} & \multicolumn{3}{|c|}{ Water content Mole $\%$} \\
\hline & & & & Exp. & PR CPA & SRK CPA \\
\hline \multirow{4}{*}{50} & \multirow{4}{*}{50} & 293.15 & 3.0 & 0.0989 & 0.1027 & 0.0973 \\
\hline & & & 6.0 & 0.0636 & 0.0712 & 0.0629 \\
\hline & & 313.15 & 3.0 & 0.2961 & 0.3080 & 0.2957 \\
\hline & & & 6.0 & 0.1791 & 0.1980 & 0.1804 \\
\hline \multirow{4}{*}{30} & \multirow{4}{*}{70} & 293.15 & 3.0 & 0.0959 & 0.0975 & 0.0934 \\
\hline & & & 6.0 & 0.0584 & 0.0627 & 0.0570 \\
\hline & & 313.15 & 3.0 & 0.2873 & 0.2949 & 0.2858 \\
\hline & & & 6.0 & 0.1693 & 0.1791 & 0.1670 \\
\hline \multirow{4}{*}{10} & \multirow{4}{*}{90} & 293.15 & 3.0 & 0.0884 & 0.0924 & 0.0894 \\
\hline & & & 6.0 & 0.0502 & 0.0554 & 0.0516 \\
\hline & & 313.15 & 3.0 & 0.2806 & 0.2817 & 0.2756 \\
\hline & & & 6.0 & 0.1543 & 0.1618 & 0.1541 \\
\hline
\end{tabular}

$\mathrm{U}(\mathrm{T}, \mathrm{k}=2)=0.1 \mathrm{~K}, \mathrm{U}(\mathrm{P}, \mathrm{k}=2)=0.04 \mathrm{MPa}$ and $\mathrm{U}_{\mathrm{c}}(\mathrm{y})=0.0006$ mole\%
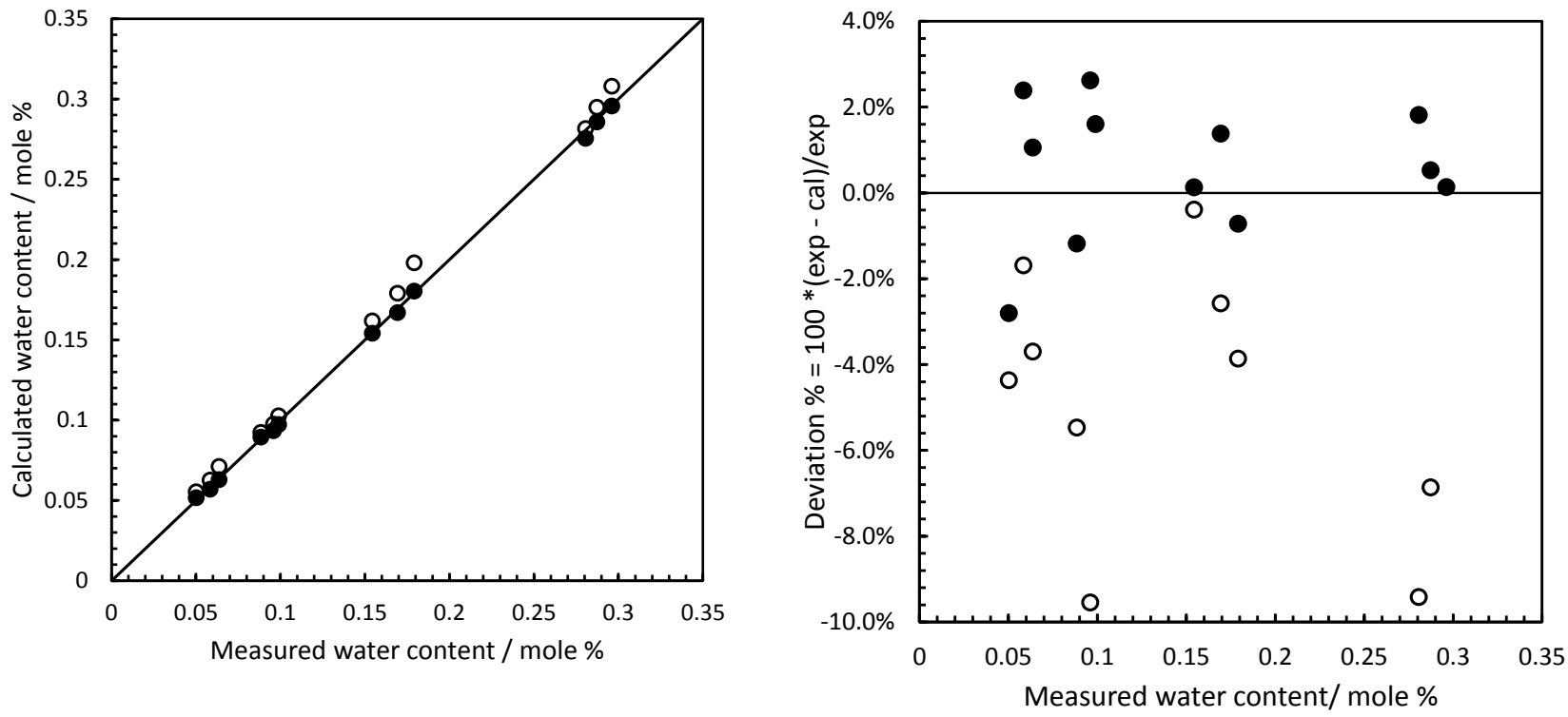

Figure 5. Comparison between experimental water content, CPA-SRK (O) and CPA-PR (O) predictions. - Left: Measured vs predicted water content; Right: Deviations between measurements and predictions. 
As can be seen in Figure 5, there is an excellent agreement between the experimental data and the models.

All the experiments presented herein were in the gas phase. The experimental data follow the expected trends, i.e.:

- $\quad$ The water content is increasing with temperature at a given pressure (Figures 6-8)

- The water content is decreasing with pressure at a given temperature (Figures 6-8)

- The water content is increasing with the $\mathrm{CO}_{2}$ concentration in the feed gas (Figures 9-10).
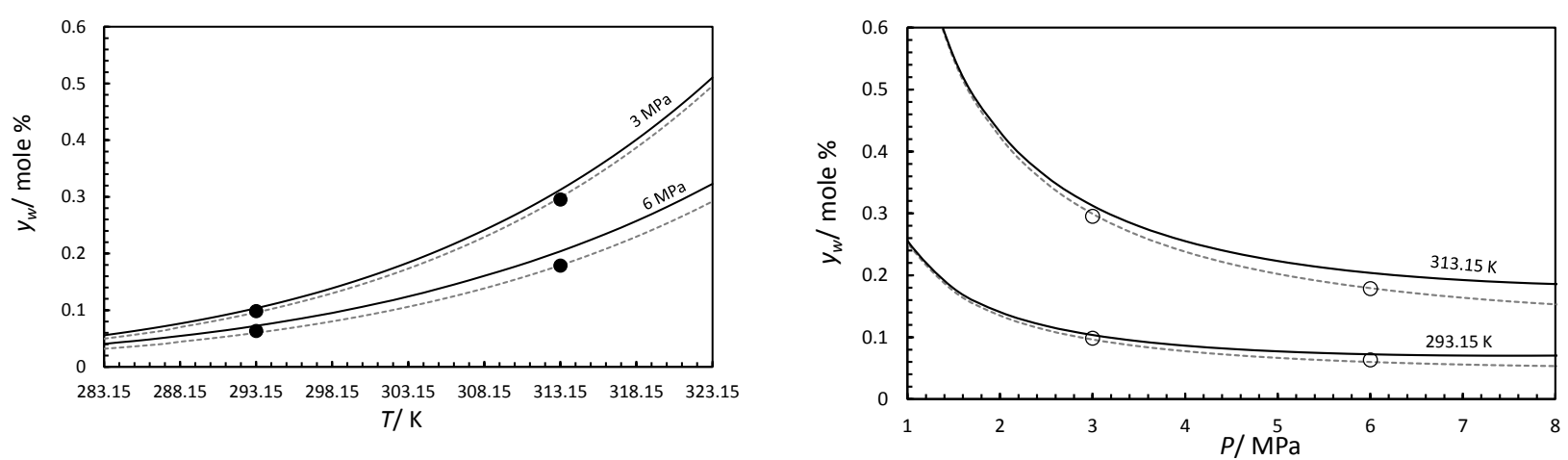

Figure 6. Predicted (Black lines: CPA-PR; Grey dotted lines: CPA-SRK) and experimental water content for the 50 mole\% $\mathrm{CO}_{2}+50$ mole $\mathrm{CH}_{4}$ system - Left: Temperature dependency; Right: Pressure dependency
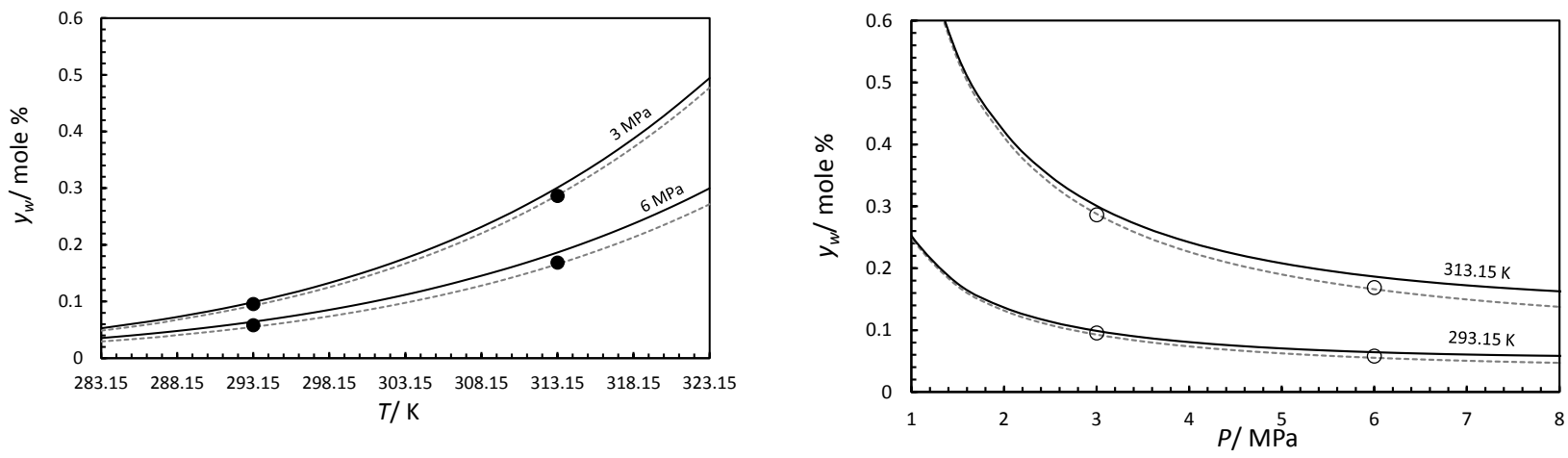

Figure 7. Predicted (Black lines: CPA-PR; Grey dotted lines: CPA-SRK) and experimental water content for the 30 mole\% $\mathrm{CO}_{2}+70$ mole $\mathrm{CH}_{4}$ system - Left: Temperature dependency; Right: Pressure dependency 

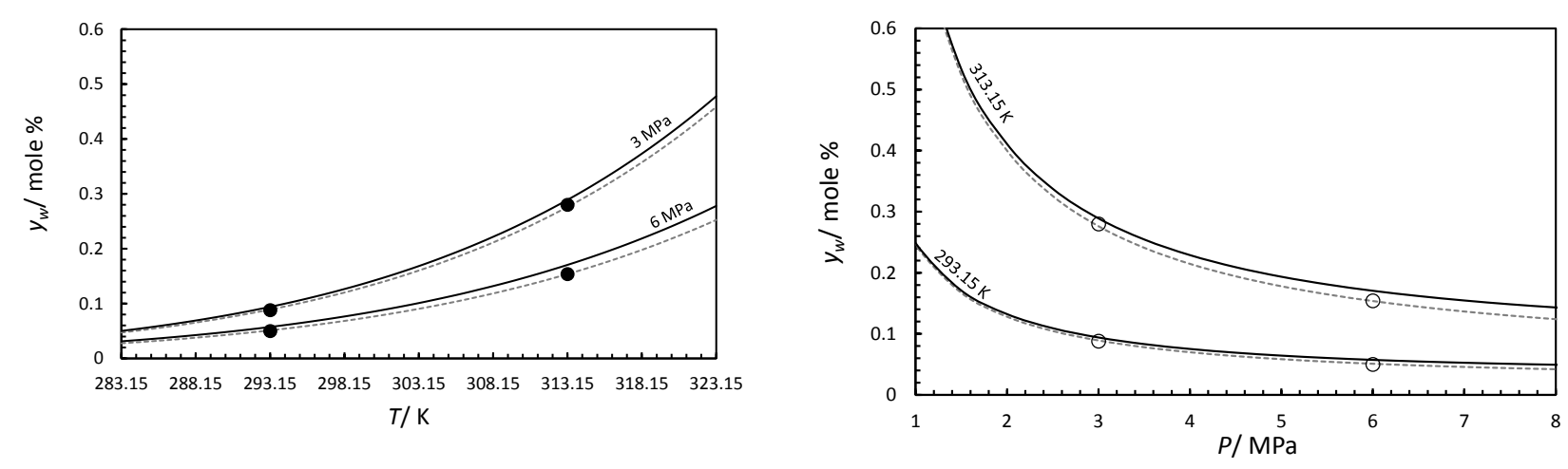

Figure 8. Predicted (Black lines: CPA-PR; Grey dotted lines: CPA-SRK) and experimental water content for the 10 mole\% $\mathrm{CO}_{2}+90$ mole $\mathrm{CH}_{4}$ system - Left: Temperature dependency; Right: Pressure dependency

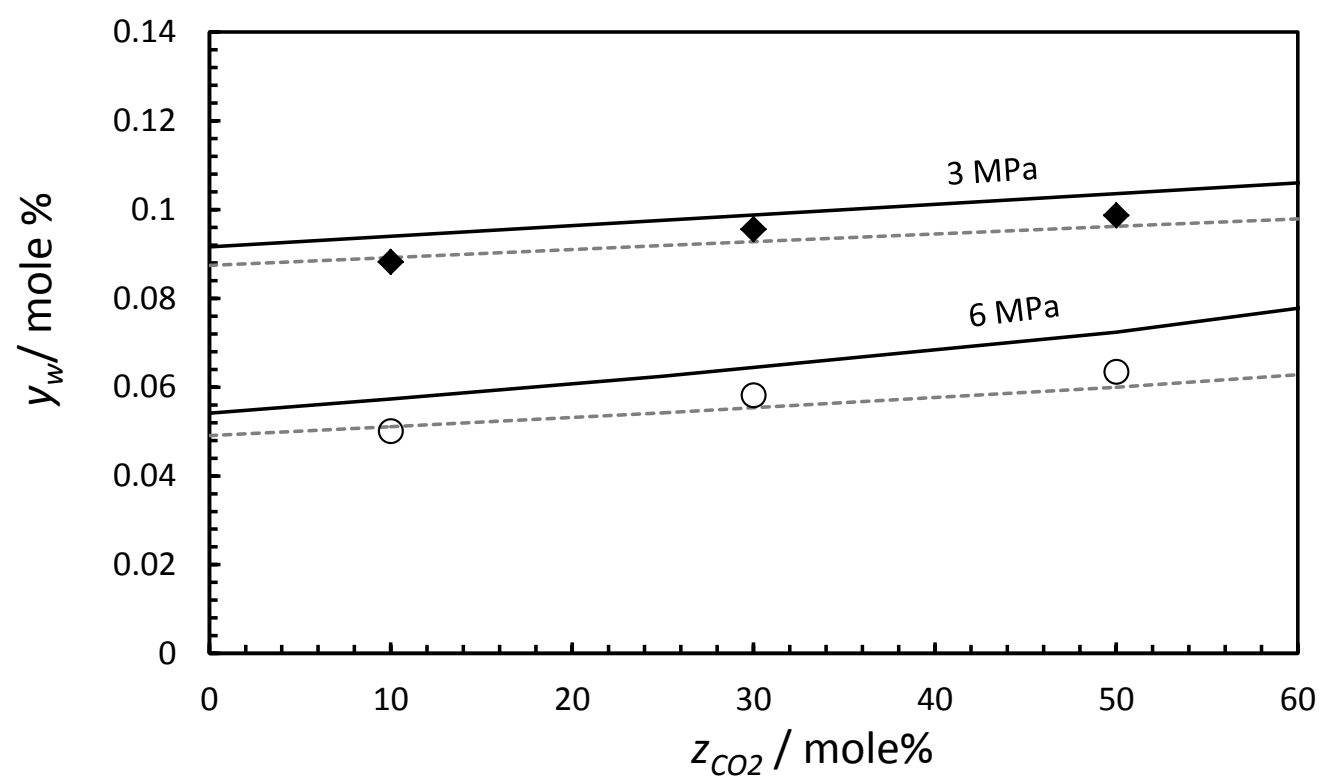

Figure 9: Predicted (Black lines: CPA-PR; Grey dotted lines: CPA-SRK) and experimental water content at $293.15 \mathrm{~K}-$ Effect of $\mathrm{CO}_{2}$ in feed gas 


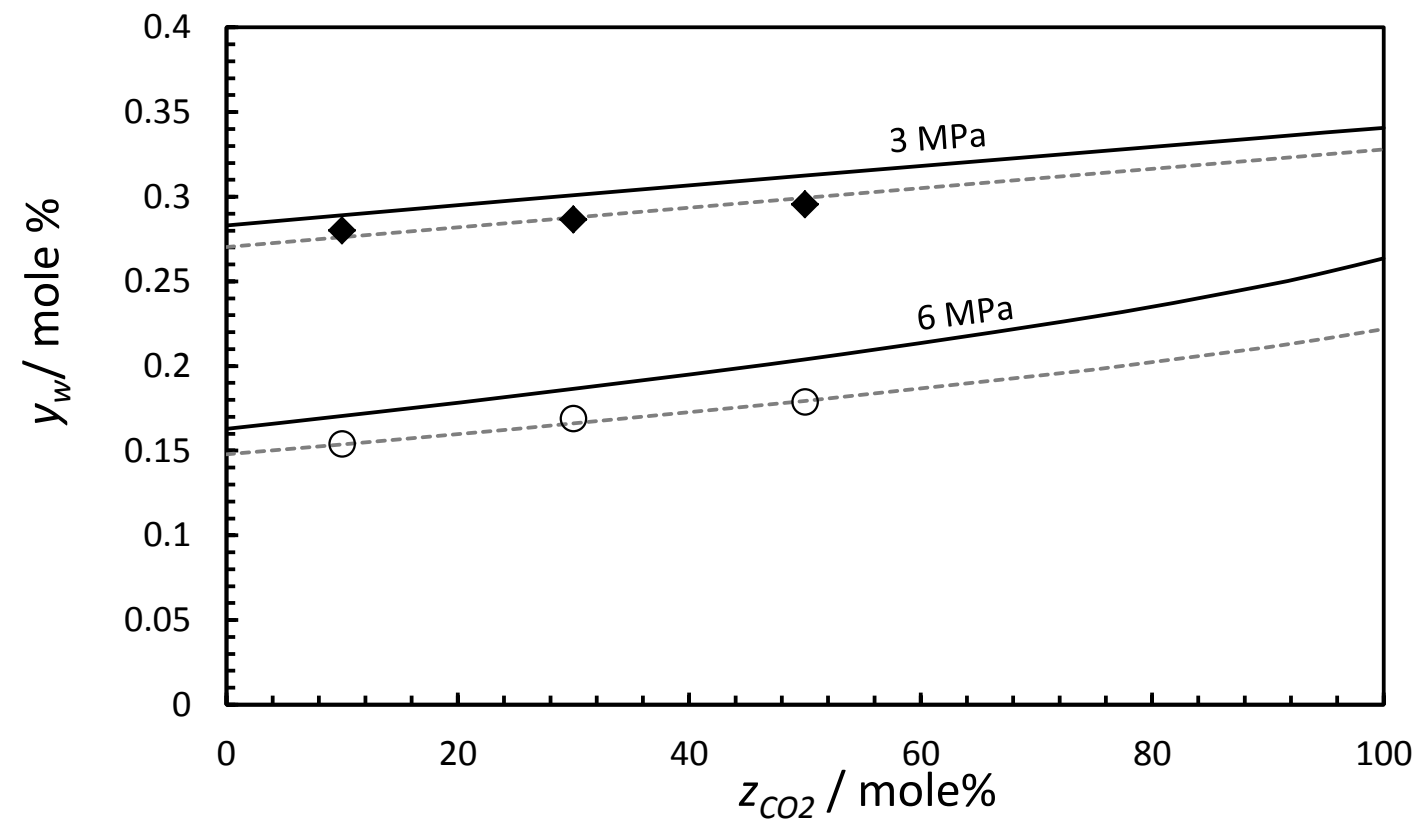

Figure 10: Predicted (Black lines: CPA-PR; Grey dotted lines: CPA-SRK) and experimental water content at $313.15 \mathrm{~K}$ - Effect of $\mathrm{CO}_{2}$ in feed gas

\section{CONCLUSION}

There is a lack of water content data for multicomponent systems containing carbon dioxide. New water content of various mixtures composed of $\mathrm{CO}_{2}$ and $\mathrm{CH}_{4}$ were determined at conditions equivalent to those encountered in industry. Both PR-EoS and SRK-EoS combined with CPA equations can predict the water content of these mixtures with good accuracy. There is still a lack of data for these systems at higher pressure, in the liquid or supercritical regions as well as in the more complex two-phase region. In the future we are planning to fill these gaps and generate measurements for more complex mixtures including other hydrocarbons.

\section{Acknowledgements}

The author would like to thanks Sandy Dunlop administrator of GPA Europe for the authorization to publish this work originally presented in September 2015 at the GPA Europe Annual meeting. 


\section{REFERENCES}

[1] J.J. McKetta and A.H. Wehe, Use This Chart for Water Content of Natural Gas, Petroleum Refiner, 37. 153-154, (1958).

[2] GPSA Engineering Data Book. $13^{\text {th }}$ Edition, (2012).

[3] A. Terrigeol, Molecular Sieves Contaminants: Effects, Consequences and Mitigation, GPA Europe Annual meeting, Berlin, (2012).

[4] A. Terrigeol, C. Coquelet and A. Chapoy, Water content Assessment in acid gas, GPA europe, Annual Conference, Florence, Italy $16^{\text {th }}-18^{\text {th }}$ September 2015.

[5] S.C. Sharma, Equilibrium Water Content of Gaseous Mixtures, Thesis, The University of Oklahoma (1969).

[6] K.Y. Song and R. Kobayashi, The Water Content of a $\mathrm{CO}_{2}$-rich Gas Mixture containing $5.31 \mathrm{~mol} \%$ Methane along the Three-Phase and Supercritical Conditions, $J$. Chem. Eng. Data, 35. 320-322, (1990).

[7] A. Dhima, J.C. de Hemptinne and J. Jose, Solubility of Hydrocarbons and $\mathrm{CO}_{2}$ Mixtures in Water under High Pressure, Ind. Eng. Chem. Res., 38. 3144-3161, (1999).

[8] J. Qin, R.J. Rosenbauer and Z. Duan, Experimental Measurements of Vapor-Liquid Equilibria of the $\mathrm{H}_{2} \mathrm{O}+\mathrm{CO}_{2}+\mathrm{CH}_{4}$ Ternary System, J. Chem. Eng. Data, 53. 12461249, (2008).

[9] A. Chapoy, H. Haghighi, R. Burgess and B. Tohidi. On the Phase Behaviour of the Carbon Dioxide - Water Systems at Low Temperatures: Experimental and Modelling, J. Chem. Therm., 47, 6-12, (2012).

[10] R. Burgass, A. Chapoy, P. Duchet-Suchaux and B. Tohidi, Experimental water content measurements of carbon dioxide in equilibrium with hydrates at (223.15 to 263.15) K and (1.0 to 10.0) MPa, J. Chem. Therm., 69. 1-5, (2014).

[11] M. Hajiw, A. Chapoy and C. Coquelet, Hydrocarbons-water phase equilibria using the CPA equation of state with a group contribution method, Can. J. Chem. Eng., 93. 432-442, (2015).

[12] M. Hajiw, A. Chapoy, C. Coquelet and G. Lauermann, Prediction of methanol content in natural gas with the GC-PR-CPA model, J. Nat. Gas Sc. Eng., in press doi:10.1016/j.jngse.2015.09.021

[13] D. Peng, and D.B. Robinson, New 2-Constant Equation of State. Ind. Eng. Chem. Fund. 15. 59-64 (1976). 
[14] M. Rigby and J. M. Prausnitz, Solubility of Water in compressed Nitrogen, Argon and Methane, J. Phys. Chem. 72, 330-334, (1968).

[15] C. Yokoyama, S. Wakana, G. Kaminishi, and S. Takahashi, Vapor-Liquid Equilibria in the Methane-Diethylene Glycol-Water System at 298.15 and $323.15 \mathrm{~K}, \mathrm{~J}$. Chem. Eng. Data, 33. 330-334, (1988).

[16] A. Chapoy, C. Cocquelet, and D. Richon, Solubility Measurement and Modeling of Water in the Gas Phase of the Methane/Water Binary System at Temperatures from 283.15 to $318.15 \mathrm{~K}$ and Pressures up to $35 \mathrm{MPa}$, Fluid Phase Equilibr. 214. 101-107, (2003).

[17] R. G. Sultanov, V. G. Skripka and A. Y. Namiot Moisture content of methane at high temperatures methane at high pressures and temperatures (in Russian), Gazov. Prom. 4. 6-13 (1971).

[18] O. L. Culberson, and J.J. McKetta, Phase Equilibria in Hydrocarbon-Water Systems III-, The solubility of methane in water at 10000 psia, Jr., Petrol. Trans. AIME 192, 223-226 (1951).

[19] F. Tabasinejad, R. G.Moore, S. A. Mehta, K. C. Van Fraassen, Y. Barzin, J. A. Rushing and K. E. Newsham, Water Solubility in Supercritical Methane, Nitrogen, and Carbon Dioxide: Measurement and Modeling from 422 to $483 \mathrm{~K}$ and Pressures from 3.6 to $134 \mathrm{MPa}$. Ind. Eng. Chem. Res. 50. 4029-4041, (2011).

[20] R. Wiebe and V.L. Gaddy, Vapor phase composition of the carbon dioxidewater mixtures at various temperatures and at pressures to $700 \mathrm{~atm}$. J. Am .Chem. Soc. 63. 475-477, (1941).

[21] P.C. Gillespie and G. M. Wilson, Vapor-liquid and liquid-liquid equilibria: water-methane, water-carbon dioxide, water-hydrogen sulfide, water-n-pentane, water-methane-n-pentane, Research report RR-48, Gas Processors Association, Tulsa, (1982).

[22] T. Nakayama, H. Sagara, K. Arai and S. Saito, High pressure liquid-liquid equilibria for the system of water, ethanol and 1,1-difluoroethane at $323.2 \mathrm{~K}$. Fluid Phase Equilibria, 38. 109-127, (1987).

[23] M.B. King, A. Mubarak, J.D. Kim and T.R. Bott, The mutual solubilites of water with supercritical and liquid carbon dioxide. J. Supercrit. Fluids. 5. 296-302 (1992). 
A. Valtz, A. Chapoy, C. Coquelet, P. Paricaud and D. Richon, D. Vapour -

liquid equilibria in the carbon dioxide - water system, measurement and modelling from 278.2 to 318.2 K. Fluid Phase Equilibr. 226. 333-344 (2004).

[25] S-X. Hou, G.C. Maitland and J. P. M. Trusler, Measurement and modeling of the phase behavior of the (carbon dioxide+ water) mixture at temperatures from 298.15 K to 448.15 K. The Journal of Supercritical Fluids. 73. 87-96 (2013).

[26] L. V. Jasperson, J. W. Kang, C. Soo Lee, D. Macklin, P. M. Mathias, R. J. McDougal, W. G. Rho, and D. VonNiederhausern, Experimental Determination of the Equilibrium Water Content of $\mathrm{CO}_{2}$ at High Pressure and Low Temperature. J. Chem. Eng. Data. 60. 2674-2683 (2015). 